\title{
Understanding water losses from irrigated pastures on loess- derived hillslopes
}

Stephanie LANGER ${ }^{1, *}$, Rogerio CICHOTA ${ }^{1}$, Steve THOMAS $^{1}$, Dirk WALLACE ${ }^{1}$, Gina VAN DER KLEI ${ }^{1}$, Mike GEORGE ${ }^{1}$, Tom JOHNS ${ }^{2}$, Peter ALMOND ${ }^{3}$, Shane MALEY ${ }^{1}$, Nathan ARNOLD ${ }^{1}$, Wei HU ${ }^{1}$, MS SRINIVASAN $^{4}$, Channa RAJANAYAKA ${ }^{4}$, Matt DODSON ${ }^{2}$, Roderick HAYMAN ${ }^{5}$ and Chandra GHIMIRE 6

${ }^{I}$ The New Zealand Institute for Plant and Food Research Ltd, Lincoln,

Private Bag 4704, Christchurch Mail Centre 8140, New Zealand

${ }^{2}$ Environment Canterbury, PO Box 345, Christchurch 8140, New Zealand

${ }^{3}$ Lincoln University, PO Box 85084, Lincoln 7647, Canterbury, New Zealand

${ }^{4}$ National Institute of Water \& Atmospheric Research Ltd (NIWA)

10 Kyle Street, Riccarton, Christchurch 8011, New Zealand

${ }^{5}$ Springbank Farm 2005 Ltd, Ford Simpson Ltd, 2nd Floor, 18 Woollcombe Street, Timaru 7910, New Zealand

${ }^{6}$ AgResearch Lincoln, Private Bag 4749, Christchurch 8140, New Zealand

*Corresponding author: Stephanie.Langer@plantandfood.co.nz

\begin{abstract}
Irrigation is likely to increase water losses from hillslopes, particularly on loess-derived soils with impeded drainage. This is important as irrigation of these soils in New Zealand is increasing. A field site was established to monitor runoff from a pasture hillslope irrigated by a centre-pivot in South Canterbury. Between November and March, 161 and $199 \mathrm{~mm}$ of irrigation was applied, $23 \%$ more at the bottom of the slope. Runoff varied with position in the hillslope, 3.5 times greater on the bottom plot $(52 \mathrm{~mm})$ compared to the top. Over the length of the slope $(40 \mathrm{~m})$ this represents a potential loss of $9 \%$ of precipitation, or $21 \%$ of the irrigation. Evidence for both saturation excess and infiltration excess runoff was observed, with antecedent soil moisture conditions being a key factor. Pasture production and water use efficiency (WUE) also varied with slope, the least $(4.6 \mathrm{t} \mathrm{DM} / \mathrm{ha}$ or $12 \mathrm{~kg}$ $\mathrm{DM} / \mathrm{ha} / \mathrm{mm}$ ) observed at the middle and most at the top of the slope $(10.1 \mathrm{t} \mathrm{DM} / \mathrm{ha}$ or $23 \mathrm{~kg} \mathrm{DM} / \mathrm{ha} / \mathrm{mm})$. This was likely due to a combination of differences in radiation and soil conditions. There was indication that pasture growth was limited by water availability at the top and potentially excess at the bottom of the slope. Our results indicate potential for improving irrigation practices.
\end{abstract}

Keywords: runoff, irrigation, water balance, fragipan, pasture

\section{Introduction}

Irrigated agriculture in New Zealand has undergone rapid expansion, doubling in area between 2002 and 2017 (Houlbrooke et al. 2011; Statistics New Zealand 2017). Moreover, the area may increase by another $33 \%$ by 2025 (Irrigation New Zealand 2020). Areas that were previously deemed less productive are now intensively farmed, increasing pressure on the environment (Houlbrooke et al. 2011). One important area where irrigation has undergone recent large-scale expansion is the downlands of South Canterbury and North Otago. These landscapes are dominated by rolling hills, underlain by loess with an almost impermeable, shallow $(\sim 60 \mathrm{~cm})$ fragipan (Webb \& Burgham 1997). Adoption of new efficient spray irrigation technology has been much faster than our understanding of the effects that this practice has on water quality in this landscape. Of the limited irrigation research in these landscapes, there is evidence that water losses occur after irrigation (Laurenson et al. 2018), and it has been suggested that that freshwater quality is likely to deteriorate even with current best farm management practices (McDowell et al. 2011).

Irrigation effects on the hydrology of the loess downlands are largely unexplored. Water movement on hillslopes is more complex than on flat land with lateral movement and variability in soil water storage being much more important (Srinivasan et al. 2002; Leh et al. 2008). In soils with fragipans, perched water tables are often generated, promoting saturation excess runoff (SER) as the water storage capacity is exceeded; infiltration excess runoff (IER) will occur when precipitation intensity exceeds soil infiltration rates. Both processes may be important in hillslopes, and have been shown to occur at the same time on hillslopes (Srinivasan et al. 2002) or alternate seasonally (Kleinman et al. 2006; Müller et al. 2006). High application intensity from centre pivot irrigation of a pasture in North Otago was proposed to lead to preferential lateral flow along the fragipan, occurring even before the soil was fully saturated (Laurenson et al. 2018). This contributed to SER at the base of the catchment where the soil reached saturation. Furthermore, this might be exacerbated through 
soil water repellency, which makes wetting slower and more uneven than would be expected based on soil hydrological characteristics (Müller et al. 2016; Bretherton et al. 2018).

Quantifying runoff from hillslopes and understanding the effect of irrigation on runoff losses are important to close surface and groundwater water and contaminant balances in the loess downland systems (Poulsen 2013). Such knowledge can be used to improve irrigation practice on farms and to develop freshwater resource management strategies. This was the driver for establishing a collaborative research programme involving Environment Canterbury, Lincoln University and the Crown Research Institutes (Plant \& Food Research, NIWA and AgResearch). In 2019, a field site was established on a dairy farm in South Canterbury. The site is a terminal catchment under a centre pivot. Within the site, plots were established to investigate hillslope runoff processes and their potential implications for pasture production and water quality. Our hypothesis was that irrigation will lead to increased surface and subsurface runoff downslope, and this is a function of hillslope hydrological processes, rainfall, and irrigation amounts and intensities.

The objectives of this study were to: (i) quantify the volume of runoff from different positions within the hillslope over an irrigation season; and (ii) identify whether there are opportunities to reduce runoff and increase water use efficiency by measuring the inputs and changes in soil water storage,. Findings from this study will be used by farmers and other stakeholders to inform any improvements in best practice or future mitigations. Information from this study on a hillslope will be used in a large catchment modelling programme to quantify catchment runoff losses and groundwater recharge.

\section{Materials and Methods}

\section{Site and experiment set up}

The experimental site consists of a small catchment (approximately $5 \mathrm{ha}$ ) at an irrigated dairy farm in Otaio, South Canterbury (-44.5S, 171.2E), which drains in an approximately east-west orientation. The runoff plots were set up on a south-facing slope at a position near the end of the centre pivot irrigator, which is approximately $340 \mathrm{~m}$ long.

The soils were classified as Fragic Perch-Gley Pallic (bottom of the slope) and Mottled Fragic Pallic (mid and top slope) according to the New Zealand soil classification (Hewitt 2010). The soils in the research area were characterised by a well-drained top soil overlaying a very poorly drained fragipan layer, which occurred in different depths along the slope, between 30 and $75 \mathrm{~cm}$ (Table 1). The top soil layer at the bottom of the slope was about three times thicker than the top soil layer in the mid and top of the slope.
In April 2019, three soil pits, positioned at the top, middle and bottom of the slope were excavated up to a depth of $180 \mathrm{~cm}$. The soil horizons in each profile were described in the field. Saturated soil hydraulic conductivity was measured at the top of each horizon in the field using a double-ring infiltrometer $(200 \mathrm{~mm}$ inner ring diameter, $300 \mathrm{~mm}$ outer ring diameter) (Touma 1992). Intact soil cores (height of $3 \mathrm{~cm}$, diameter of $5 \mathrm{~cm}$, two replicates per horizon) were carefully extracted for laboratory measurements of soil water retention on tension tables and pressure chambers (Hu et al. 2018), and bulk density (Hu et al. 2018). Additional soil taken from each horizon was sieved (4 $\mathrm{mm}$ ), air dried for textural analysis using the pipette method (Gee 2002) and total organic carbon content using Dumas combustion (LECO) (Rutherford 2008). A summary of these properties is given in Table 1.

Depending on the thickness of the soil horizon, between two and four soil moisture probes (CS650, Campbell scientific instruments, UT, US) were installed in each soil horizon facing up and across the slope to monitor the variation in the soil water content.

Runoff plots were built in September 2019 adjacent to the three soil water monitoring arrays. Each plot consisted of a rectangle $4 \mathrm{~m}$ wide $\times 10 \mathrm{~m}$ long, which were positioned approximately parallel to the tracks of the centre pivot. Timber boards $(150 \mathrm{~mm} \times 25 \mathrm{~mm})$ were partially buried along the plot edges to prevent surface water from the surrounding area entering the plots during rainfall or irrigation events. There was a buffer of approximately $2.5 \mathrm{~m}$ between the top and middle and middle and bottom plots. The overall slope length was approximately $40 \mathrm{~m}$. At the bottom end of each plot, the surface water was collected in a gutter and funnelled into a 100-L collection bin. Collected water was then pumped through a flowmeter (HRI, Sensus Metering Systems, UK), with a subsample of the runoff water stored automatically in a second 72 L sampling bin while the remaining water was discharged away from the plots. The average downward slope for each plot was $4^{\circ}, 18^{\circ}$ and $15^{\circ}$ for the top, middle and bottom plots respectively. The area containing the runoff plots was fenced off to keep the cows off the experiment. Runoff volumes were divided by projected plot area to give runoff in $\mathrm{mm}$. Two tipping-spoon rain gauges $(6463 \mathrm{M}$, Davis Instruments, US; $0.2 \mathrm{~mm}$ per tip) were installed at the base of each runoff plot to measure rainfall and irrigation. Rainfall, and other weather variables, were also measured at a NIWA compact weather station, which was installed in December 2018 outside the irrigated area approximately $500 \mathrm{~m}$ from the experimental site. A GPS tracker (Oyster 2G/3G Cellular, Digital Matter, AU) was installed at the end of the centre pivot to remotely monitor its position. 
Table 1 Soil properties for different horizons of three pits representing the bottom, middle and top of the slope. Field capacity was defined as the water content at $-10 \mathrm{kPa}$ and wilting point at $-1500 \mathrm{kPa}$. NA=not available.

\begin{tabular}{|c|c|c|c|c|c|c|c|c|c|c|}
\hline \multirow[t]{2}{*}{$\begin{array}{l}\text { Slope } \\
\text { position }\end{array}$} & Depth & Horizon & $\begin{array}{c}\text { Bulk } \\
\text { density }\end{array}$ & $\begin{array}{c}\text { Wilting } \\
\text { point }\end{array}$ & $\begin{array}{c}\text { Field } \\
\text { capacity }\end{array}$ & $\begin{array}{c}\text { Saturated } \\
\text { hydraulic } \\
\text { conductivity }\end{array}$ & $\begin{array}{l}\text { Carbon } \\
\text { content }\end{array}$ & $\begin{array}{l}\text { Sand } \\
\geq 53 \mu \mathrm{m}\end{array}$ & $\begin{array}{l}\text { Silt } \\
<53 \mu \mathrm{m} \\
>2 \mu \mathrm{m}\end{array}$ & $\begin{array}{l}\text { Clay } \\
\leq 2 \\
\mu \mathrm{m}\end{array}$ \\
\hline & $(\mathrm{cm})$ & & $\left(\mathrm{g} / \mathrm{cm}^{3}\right)$ & $\begin{array}{c}\left(\mathrm{cm}^{3}\right. \\
\text { water/cm } \\
\text { soil }\end{array}$ & $\begin{array}{c}\left(\mathrm{cm}^{3}\right. \\
\text { water/cm } \\
\text { soil) }\end{array}$ & (mm/day) & (\%) & (\%) & $(\%)$ & (\%) \\
\hline \multirow[t]{5}{*}{ Bottom } & $0-30$ & Ap1 & 1.32 & 0.23 & 0.34 & 314 & 1.86 & 4.7 & 72.5 & 22.8 \\
\hline & $31-56$ & Ap2 & 1.32 & 0.24 & 0.36 & 94 & 1.24 & 4.2 & 71.1 & 24.7 \\
\hline & $57-68$ & $A b$ & 1.44 & 0.22 & 0.31 & 338 & 0.72 & 4.8 & 70.5 & 24.7 \\
\hline & $69-76$ & $\mathrm{Bg}$ & 1.51 & 0.21 & 0.3 & NA & 0.42 & 4.5 & 71.3 & 24.3 \\
\hline & $77-180+$ & $B x(g)$ & 1.52 & 0.19 & 0.26 & 304 & 0.32 & 4.8 & 73.0 & 22.3 \\
\hline \multirow[t]{4}{*}{ Middle } & $0-15$ & Ap & 1.32 & 0.24 & 0.35 & 1243 & 2.47 & 5.5 & 73.2 & 21.3 \\
\hline & $16-30$ & $B w(g)$ & 1.48 & 0.21 & 0.29 & 990 & 0.38 & 4.5 & 74.7 & 20.8 \\
\hline & $31-120$ & $B x(g)$ & 1.44 & 0.2 & 0.28 & 15 & 0.37 & 4.7 & 73.5 & 21.7 \\
\hline & $121-150+$ & bBt(g) & 1.59 & 0.21 & 0.28 & NA & 0.17 & 4.9 & 64.7 & 30.4 \\
\hline \multirow[t]{4}{*}{ Top } & $0-17$ & Ap & 1.39 & 0.25 & 0.36 & 220 & 2.53 & 5.0 & 72.0 & 23.0 \\
\hline & $18-29$ & $\mathrm{~A} / \mathrm{Bw}$ & 1.45 & 0.2 & 0.29 & 281 & 1.55 & 4.7 & 70.8 & 24.5 \\
\hline & $30-62$ & $B w(g)$ & 1.46 & 0.16 & 0.24 & NA & 0.63 & 4.8 & 72.5 & 22.7 \\
\hline & $63-170+$ & $\mathrm{Bx}(\mathrm{g})$ & 1.70 & 0.2 & 0.26 & 277 & 0.19 & 4.3 & 73.7 & 22.0 \\
\hline
\end{tabular}

\section{Maintenance and data collection}

The pasture inside the plots was cut every 3 to 5 weeks, roughly lining up with the grazing periods. Grass was cut using a lawn mower to a height of approximately $5 \mathrm{~cm}$, representing the post-grazing residual of approximately $1700 \mathrm{~kg} \mathrm{DM} / \mathrm{ha}$. Dry matter yield was determined from two $0.5 \mathrm{~m}$ wide strips down the length of each plot. The harvested material was weighed and a subsample of approximately $300 \mathrm{~g}$ was used to determine the dry matter percentage (dried until constant weight achieved). The area of each individual strip was calculated and used to determine pasture yield. After each grass cut, approximately $18 \mathrm{~kg} \mathrm{~N} / \mathrm{ha}$ in the form of urea (Ballance SustaiN ${ }^{\circledR}$ ) was applied, matching the farmer's fertiliser application plan. Irrigation applications followed the general farm management with timing and depth of application varying over time. Individual events applied on average a depth of $6.5 \mathrm{~mm}$ of water, ranging between 4.0 and $14 \mathrm{~mm}$.

All the data from the sensors (soil moisture, precipitation, weather data, GPS position) were recorded every 10 minutes using a data logger(CR1000, Campbell Scientific Instruments, UT, US) and relayed via a communication system to a Neon Server, which is available in real time to researchers and the farmer. Runoff was recorded whenever the collected water was pumped through the flowmeter. Any remaining runoff was recorded manually every time the pasture was cut and added to the runoff total, which was also stored in the same server.

\section{Data analyses}

The amount of irrigation was determined as the difference between the measured precipitation at each plot and the rainfall amount measured at the NIWA Otaio weather station. The actual occurrence and the timing of irrigations were confirmed by cross-checking the precipitation measurement on plots and the movement of the centre pivot monitored by GPS. Water balance calculations were done using the approach described in Woodward et al. (2001), using potential evapotranspiration (PET) sourced from the Timaru weather station. Soil water holding capacity was determined based on lab measurements (field capacity minus permanent wilting point, Table 1) for horizons which exhibited noticeable variation in soil moisture above the fragipan (yielding $54 \mathrm{~mm}, 53 \mathrm{~mm}$ and $83 \mathrm{~mm}$ for the plots at the top, middle and bottom of the slope). The same values were also used to compute soil water deficits. Water use efficiency (WUE) was estimated as the amount of dry matter produced per mm of rainfall and irrigation.

\section{Results}

\section{Water balance}

Due to above-average spring rainfall, the first irrigation was only applied on 27 November 2019 and the last was on 17 March 2020. A total of 25 irrigation events were recorded over this period totalling $199 \mathrm{~mm}$ of irrigation at the bottom of the slope, and $161 \mathrm{~mm}$ and 
$163 \mathrm{~mm}$ at the mid and top of the slope, respectively. Irrigation applied varied between 5 and $14 \mathrm{~mm}$ for individual events. The irrigation complemented the $240 \mathrm{~mm}$ of rainfall recorded from 1 November 2019 to 31 March 2020 (Figure 1). For the same period, PET totalled $531 \mathrm{~mm}$ (Timaru weather station). The amount of precipitation (irrigation plus rainfall) recorded by the six rain gauges on site was consistent for each plot, but the amount of applied irrigation was considerably larger at the bottom of the slope, by approximately $23 \%$. The recorded precipitation did not meet the PET totals for the period (Figure 1), suggesting some water stress was experienced by the pasture, especially when considering that runoff also occurred.

Runoff was registered in all the three plots, in spite of the existing water deficits (Figure 1). The largest runoff event observed over the season was recorded on 6 December, resulting from a combination of rainfall $(18 \mathrm{~mm}$ ) following irrigation (approximately $21 \mathrm{~mm}$ in the previous 6 days). Cumulative runoff measured for the period between 1 November and 31 March varied with the position in the slope. At the top of the slope only $13 \mathrm{~mm}$ was recorded, compared to $34 \mathrm{~mm}$ at the middle and $45 \mathrm{~mm}$ at the bottom of the slope. This was the equivalent of 4,10 and $12 \%$ of the total precipitation or 10,24 and $26 \%$ of the irrigation for the top, middle and bottom of the slope, respectively. The total runoff volume from the three plots was $3.97 \mathrm{~m}^{3}$, which equates to $32.7 \mathrm{~mm}$ across the slope, equivalent to $8.7 \%$ of the total precipitation or $20.1 \%$ of the irrigation.

Soil moisture measurements indicated that plant water extraction occurred only from the top $60 \mathrm{~cm}$ of the soil, with a small decrease in water content below this depth for the top-slope plot only. Soil water responses varied depending on the position on the slope. The lowest volumetric soil water content in the top $30 \mathrm{~cm}$ of soil was measured at the top (26\%) indicating the pasture would have been under stress (Table 1). Minimum soil water contents were much higher downslope; $31 \%$ at the middle and $36 \%$ at the bottom of the slope. Soil water deficits are used here to illustrate the variations in hydrological behaviour among the different plots (Figure 2). The top-slope showed a consistent build up in water deficit over the season, reaching its maximum at the start of February when its magnitude was nearly equal to the total water holding capacity of the soil layers above the fragipan. These deficits indicate that growth would have been limited during January and February. There was no indication of water stress downslope. Deficits reached at the middle of the slope were considerably smaller and were even less at the bottom-slope (Figure 2). For the bottom-slope, the deficit was returned to zero on a few occasions following precipitation and aligned well
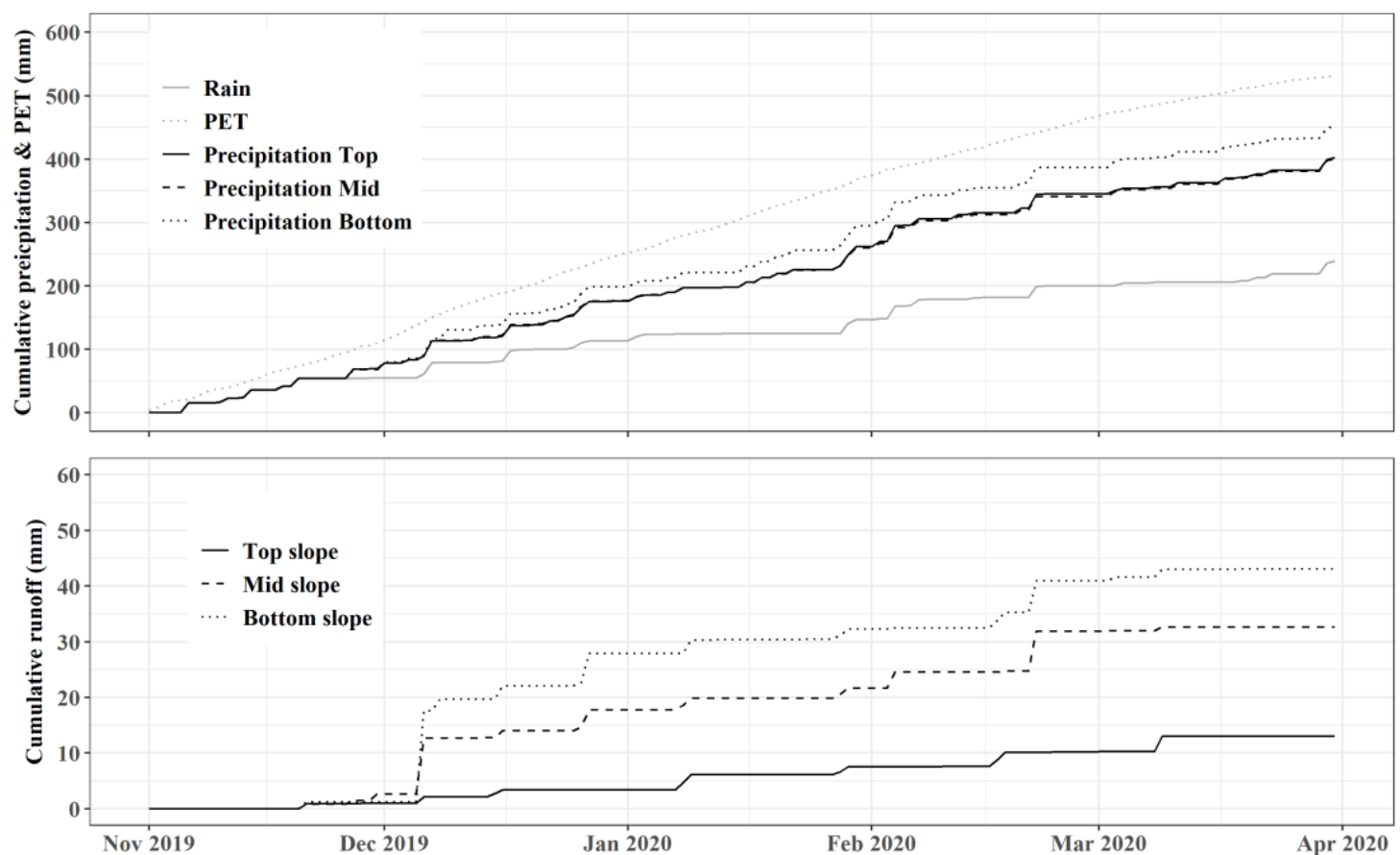

Figure 1 Summary of water flows recorded at three isolated runoff plots. Top graph shows the cumulative values for PET, rainfall, and total precipitation (rain + irrigation between 1 November 2019 and 31 March 2020. Bottom graph shows the cumulative runoff values for the three plots for the same period. 

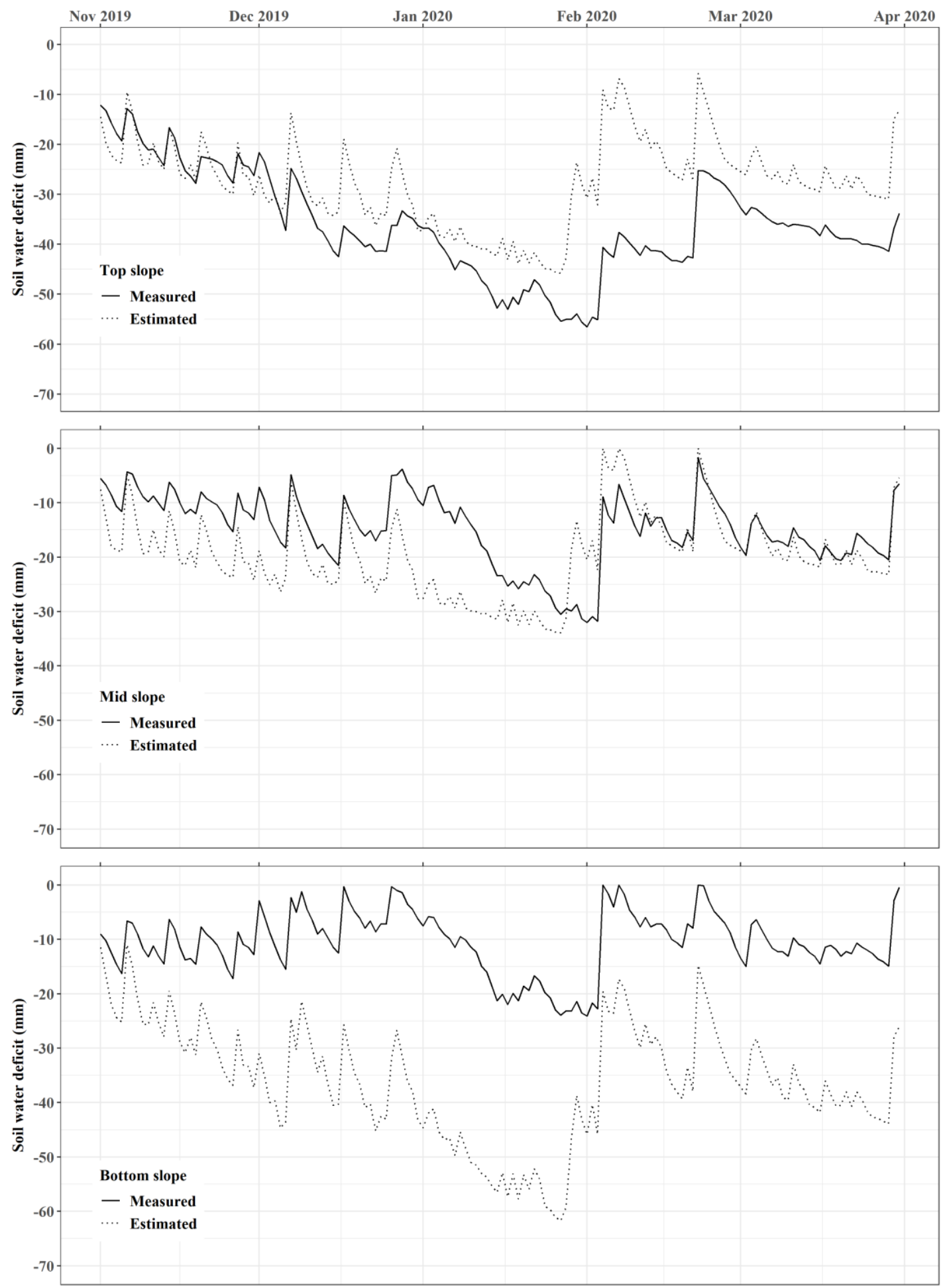

Figure 2 Measured and estimated soil water deficits between 1 November 2019 and 31 March 2020 for the three runoff plots on a slope at a dairy farm in South Canterbury. The water balance was initialised on 30 October 2019, using measured values. Estimates were based on the water balance approach of Woodward et al. (2001). Water holding capacities above the fragipan were $54 \mathrm{~mm}, 53 \mathrm{~mm}$ and $83 \mathrm{~mm}$ (based on laboratory measurements) for the top, mid and bottom plot. 
with runoff measurements indicating SER was the main driver. For the lower two plots, but especially for the middle slope, water content below $60 \mathrm{~cm}$ did increase during the season, peaking at the start of February, again suggesting water was flowing in from the upper slope. The large discrepancy between measured and estimated soil water deficit (Figure 2) can also be seen as evidence that a simple modelling approach does not capture all relevant processes in these loess slopes. They do however, provide evidence for an additional source of water into the soil profiles down the slope. Although reduced evapotranspiration would also have contributed to the differences.

\section{Dry matter production and water use efficiency}

Dry matter production was also greatly affected by the position on the slope. Pasture production was greater at the top of the slope, reaching $10.1 \mathrm{t} / \mathrm{ha}$ over the November-March period, whereas the least $(4.6 \mathrm{t} / \mathrm{ha})$ was produced at the middle of the slope and $6.7 \mathrm{t} / \mathrm{ha}$ at the bottom of the slope. Highest growth rates occurred in spring (November) at the top of the slope $(106 \mathrm{~kg}$ $\mathrm{DM} / \mathrm{ha} / \mathrm{d}$ ), whereas over the same period growth on the middle of slope was $43 \mathrm{~kg} \mathrm{DM} / \mathrm{ha} / \mathrm{d}$, or $41 \%$ of that on the top. Growth rates declined over the summer period (December-February) to an average of 69 and $31 \mathrm{~kg} \mathrm{DM} /$ $\mathrm{ha} / \mathrm{d}$ for the top and middle slope, respectively, and $44 \mathrm{~kg}$ $\mathrm{DM} / \mathrm{ha} / \mathrm{d}$ at the bottom of the slope. Water use efficiency was directly affected by these growth differences, as similar amounts of rainfall and irrigation were applied to all plots. Based on the amount of precipitation over the November-March period, WUE was greatest at the top $(23 \mathrm{~kg} \mathrm{DM} / \mathrm{mm})$, smallest in the middle $(12 \mathrm{~kg}$ $\mathrm{DM} / \mathrm{mm})$, and intermediate at the bottom of the slope $(17 \mathrm{~kg} \mathrm{DM} / \mathrm{mm})$. Based on dry matter production and WUE, it is clear that water use and requirements would have differed greatly down the slope, with much lower requirements in the middle and bottom areas.

\section{Discussion}

Our results show that runoff from irrigated hillslopes can be a considerable proportion of water inputs. The combination of soil wetting by irrigation and a following rainfall event led to the largest runoff events. The size of these events indicates that saturation excess runoff (SER) occurred, with wet antecedent soil conditions likely being a major contributor for runoff generation. This runoff happened early in the season on the plots at the top and middle of the slope, while it was the case over all of the season for the bottom slope plot. The ability to predict rainfall events and manage irrigation accordingly might have avoided or reduced the risk of runoff. Maintaining a large soil deficit could be an alternative, but managing the variation in moisture status along the slope would be a challenge.
There were runoff events in January that were linked to irrigation only, when the soil water deficit was considerably greater than the irrigation amount in all plots, suggesting infiltration excess runoff (IER) also occurred. The occurrence of both SER and IER processes at the same location is well documented (Srinivasan et al. 2002; Kleinman et al. 2006; Müller et al. 2006). SER is expected when the soil has low deficits, while the prevalence of IER during summer, when soil is dry, may indicate also the presence of hydrophobicity (Müller et al. 2016; Bretherton et al. 2018). The importance of IER as a driver of runoff has been proposed for a similar catchment and that it might also be linked to preferential subsurface flow which bypasses soil storage (Laurenson et al. 2018). Similar to Laurenson et al. (2018) study, the hydraulic conductivity of the soil in our work was greater (Table 1) than the instantaneous irrigation intensities estimated at the experimental site $(20-30 \mathrm{~mm} / \mathrm{h}$ based on the GPS and rain-gauge data), or what could be expected for the irrigation system (Powers 2012). Furthermore, soil moisture sensor data indicate that there might be considerable subsurface bypass flow at both the middle and bottom of the slope. In particular we observed increases in water content above the shallow fragipan in the middle of the slope, such increase could not be explained by the water balance. The large difference between the water deficits predicted by the water balance and that inferred from soil moisture measurements can be seen as evidence for wetting of the profile other than precipitation. The increase in average moisture at deep layers and generation of runoff is strong evidence for subsurface bypass flow (Leh et al. 2008; Laurenson et al. 2018).

Hydrological characteristics are commonly highly variable in hillslopes and our data corroborate this. Ideally farming management practices have to follow site-specific characteristics to ensure the best use of resources and avoid losses (Hedley 2015). However, in practical terms, measuring or estimating soil water and/or water usage spatially is currently limited and overcoming such limitations should be a goal for future sensor and modelling developments for irrigation management. Employing variable rate irrigation systems (Hedley et al. 2010) could be an option to manage the areas at the top and down the slope differently. This can be important to manage not only variations in the soil, but also in landscape position. Furthermore, our measurements indicated that the irrigation inputs were also variable, where the bottom end of the slope received $23 \%$ more irrigation than the top plots; this could be an indication that there was considerable difference in hydraulic pressure leading to a greater flow (hence greater irrigation depth). These results occurred even though the GPS data showed that 
the irrigator speed was consistent within the experiment site. The ability to vary irrigation application spatially across the hillslopes as well as temporally should be an important consideration in selecting and improving irrigation systems.

The position on the slope had a strong impact on pasture production and water use, with the top of the slope producing between 50 and $100 \%$ more than the bottom and middle of the slope, even though the lower plots received similar amounts of precipitation and remained wetter. Water use efficiency provides an indicator of how well irrigation or rainfall is used. A value of about $20 \mathrm{~kg} \mathrm{DM} / \mathrm{ha} / \mathrm{mm}$ is considered to be good for irrigated pasture (Martin et al. 2006). So while this was exceeded at the top of the slope $(23 \mathrm{~kg} \mathrm{DM} /$ $\mathrm{ha} / \mathrm{mm}$ ), water was not well utilised down the slope, with 12 and $17 \mathrm{~kg} \mathrm{DM} / \mathrm{ha} / \mathrm{mm}$ at the middle and bottom slope, respectively. Based on the high measured soil water contents we assume that production was not limited by water availability, and that irrigation could have been reduced without impacting on production. Reducing irrigation without affecting production would increase WUE. Availability of nutrients, and incident solar radiation, factors that are linked to the slope and aspect of the area (Gillingham 1974; Lambert et al. 1983; Nicholas 1999) may also have affected pasture growth. While we did not measure the effect of aspect on incident radiation on the pasture, this would be important as it is directly related to PET and plant growth (Radcliffe \& Lefever 1981). Lower fertility may also have been an important contributor for lower yields at the mid slope, giving the difficulty in applying fertiliser at these slopes $\left(18^{\circ}\right)$ and the potential that some of the applied amount would be transported away. This is true for the bottom plot (with slope of $15^{\circ}$ ), but poor aeration reducing growth due to excess water may have also been important. Soil fertility and the nutrient transport by surface runoff was not part of the current experiment, but should be considered in the future to determine the key drivers of pasture growth and environmental impact. Furthermore, the experiment setup excluded livestock, so this factor cannot be evaluated in the present study.

\section{Conclusions}

Our findings provide insights on the challenges and opportunities for improving irrigation practices in rolling landscapes. Runoff occurred in all of our plots, but especially on steeper slopes. Understanding the key factors controlling the generation of runoff will be important to modify irrigation practices and/or equipment. This will be challenging as it relies on good estimates or measures of soil water storage. Our results show that a simple water balance model is not suitable for hillslope landscapes.
Our estimates of water use efficiency suggests limitations for pasture growth varied due to under- and over-irrigation in different parts of the slope. Precision based technology, such as Variable Rate Irrigation, could be used to apply differential and smaller amounts of water across the hillslopes to overcome the spatially (and temporally) variation in pasture water requirements that are a function of these hillslope systems (i.e. the effects of water storage, slope aspect, and differences in nutrient status).

While our work has focused on hydrology, it is reasonable to assume that the presence of runoff is likely to increase the transport of contaminants. This is a further reason for investigating and applying improved irrigation methodologies on hillslopes. New studies should also focus on not just the irrigation but also on its interaction with wider farm system management such as grazing and fertiliser schedules.

\section{ACKNOWLEDGEMENTS}

This work was partially funded by the Sustainable Agro-Ecosystems (SAE) programme development fund from The New Zealand Institute for Plant and Food Research Limited. We thank B. Chard for his help with our field work. R. White, S. Glasson, R. Tregurtha and P. Godson for their help with soil sampling and analyses. J. Liu for his help with the data exploration. We also want to acknowledge Abigail Lovett for her strong supporting role in the Hillslope Research Collaboration.

\section{REFERENCES}

Bretherton M, Horne D, Sumanasena HA, Jeyakumar P, Scotter D. 2018. Repellency-induced runoff from New Zealand hill country under pasture: A plot study. Agricultural Water Management 201: 83-90. https:// doi.org/10.1016/j.agwat.2018.01.013

Gee GO, D 2002. Particle size analysis. In: Dame JT, GC Ed. Methods of Soil Analysis - Part 4 - Physical Methods, pp. 255-293. Madison, Wisconsin: Soil Science Society of America. https://doi.org/10.2136/ sssabookser5.4.c12

Gillingham AG. 1974. Influence of physical factors on pasture growth on hill country. Proceedings of the New Zealand Grassland Association 35: 77-85. https://doi.org/10.33584/jnzg.1973.35.1370.

Hedley C. 2015. The role of precision agriculture for improved nutrient management on farms. Journal of the Science of Food and Agriculture 95: 12-19. https://doi.org/10.1002/jsfa.6734

Hedley CB, Bradbury S, Ekanayake J, Yule I, Carrick S. 2010. Spatial irrigation scheduling for variable rate irrigation. Proceedings of the New Zealand Grassland Association 72: 97-102. https://doi. org/10.33584/jnzg.2010.72.2831 
Hewitt AE. 2010. New Zealand soil classification, 3rd ed. Lincoln, New Zealand: Manaaki Whenua Press, $136 \mathrm{p}$.

Houlbrooke DJ, Paton RJ, Littlejohn RP, Morton JD. 2011. Land-use intensification in New Zealand: effects on soil properties and pasture production. Journal of Agricultural Science 149: 337-349. https://doi.org/10.1017/S0021859610000821

Hu W, Tabley F, Beare M, Tregurtha C, Gillespie R, Qiu W, Gosden P. 2018. Short-term dynamics of soil physical properties as affected by compaction and tillage in a silt loam soil. Vadose Zone Journal 17: 180115. https://doi.org/10.2136/vzj2018.06.0115

Irrigation New Zealand. 2020. Value of Irrigation. Lincoln, New Zealand. https://www.irrigationnz. co.nz/Article?Action $=$ View\&Article $\mathrm{id}=13$

Kleinman PJA, Srinivasan MS, Dell $\bar{C}$ J, Schmidt JP, Sharpley AN, Bryant RB. 2006. Role of rainfall intensity and hydrology in nutrient transport via surface runoff. Journal of environmental quality 35: 1248-1259. https://doi.org/10.2134/jeq2006.0015

Lambert MG, Clark DA, Grant DA, Costall DA, Fletcher RH. 1983. Influence of fertiliser and grazing management on North Island moist hill country 1. Herbage accumulation. New Zealand Journal of Agricultural Research 26: 95-108. https://doi.org/10. 1080/00288233.1983.10420958

Laurenson S, Cichota R, Reese P, Breneger S. 2018. Irrigation runoff from a rolling landscape with slowly permeable subsoils in New Zealand. Irrigation Science 36: 121-131. https://doi.org/10.1007/ s00271-018-0570-3

Leh MD, Chaubey I, Murdoch J, Brahana JV, Haggard BE. 2008. Delineating runoff processes and critical runoff source areas in a pasture hillslope of the Ozark Highlands. Hydrological Processes 22: 4190-4204. https://doi.org/10.1002/hyp.7021

McDowell RW, van der Weerden TJ, Campbell J. 2011. Nutrient losses associated with irrigation, intensification and management of land use: A study of large scale irrigation in North Otago, New Zealand. Agricultural Water Management 98: 877885. https://doi.org/10.1016/j.agwat.2010.12.014

Müller K, Stenger R, Rahman A. 2006. Seasonal variation of 24D export through surface runoff from pasture. New Zealand Plant Protection 59: 255-260. https://doi.org/10.1016/j.still.2016.03.010

Müller K, Carrick S, Meenken E, Clemens G, Hunter D, Rhodes P, Thomas S. 2016. Is subcritical water repellency an issue for efficient irrigation in arable soils? Soil and Tillage Research 161: 53-62.

Nicholas PK. 1999. Environmental and management factors as determinants of pasture diversity and production of North Island, New Zealand hill pasture systems. PhD thesis, Massey University, Palmerston North $255 \mathrm{p}$.

Poulsen D. 2013. The hydrogeological significance of loess in Canterbury R13/60. Christchurch: Environment Canterbury Regional Council, 59 p. https://api.ecan.govt.nz/TrimPublicAPI/documents/ download/1853775

Powers JW. 2012. Defining practical limits for centre-pivot length and irrigation management on Lismore soils. Masters thesis, Lincoln University, Christchurch, New Zealand, 115 p.

Radcliffe JE, Lefever KR. 1981. Aspect influences on pasture microclimate at Coopers Creek, North Canterbury. New Zealand Journal of Agricultural Research 24: 55-56. https://doi.org/10.1080/002882 33.1981.10420871

Rutherford PM, McGill WB, Arocenaet JM. 2008. 22.4 Dumas Methods. In: Carter MR, Gregorich EG Eds. Soil sampling and methods of analysis. 2nd ed., pp. 247-248. Boca Raton, FL, USA: CRC Press.

Srinivasan M, Gburek W, Hamlett J. 2002. Dynamics of stormflow generation - A hillslope-scale field study in east-central Pennsylvania, USA. Hydrological Processes 16: 649-665. https://doi.org/10.1002/ hyp. 311

Statistics New Zealand. 2017. Agricultural production statistics: June 2017 (final). Retrieved 25 January 2020 from https://www.stats.govt.nz/informationreleases/agricultural-production-statistics-june2017-final

Touma JA, J. 1992. Determining soil hydrologic properties from rain simulator or double ring infiltrometer experiments: a comparison. Journal of Hydrology 135: 73-86. https://doi.org/10.1016/00221694(92)90081-6

Webb TH, Burgham SJ. 1997. Soil-landscape relationships of downlands soils formed from loess, eastern South Island, New Zealand. Australian Journal of Soil Research 35: 827-842. https://doi. org/10.1071/S96077

Woodward SJR, Barker DJ, Zyskowski RF. 2001. A practical model for predicting soil water deficit in New Zealand pastures. New Zealand Journal of Agricultural Research 44: 91-109. https://doi.org/10. 1080/00288233.2001.9513464 